\title{
Water Infiltration Study from Magnetotelluric Data in the Limestone Fault Network of Mintom (South Cameroon)
}

\author{
Harlin L. Ekoro Nkoungou ${ }^{1,2}$, Daniel H. Gouet ${ }^{1,3}$, Philippe Njandjock Nouck1, \\ Eliézer Manguelle Dicoum ${ }^{1}$ \\ ${ }^{1}$ Department of Physics, Faculty of Science, University of Yaounde I, Yaounde, Cameroon \\ ${ }^{2}$ International Institute for Water and Environmental Engineering, Ouagadougou, Burkina Faso \\ ${ }^{3}$ Institute of Mining and Petroleum Industries, University of Maroua, Maroua, Cameroon \\ Email: harlybr2002@yahoo.fr
}

Received 18 July 2015; accepted 21 September 2015; published 24 September 2015

Copyright (C) 2015 by authors and Scientific Research Publishing Inc.

This work is licensed under the Creative Commons Attribution International License (CC BY). http://creativecommons.org/licenses/by/4.0/

c) (i) Open Access

\begin{abstract}
Magnetotelluric surveys have been conducted in the Mintom area in order to evaluate the water infiltration potential of the Dja river in a limestone deposit estimated at about $350 \mathrm{million} \cdot \mathrm{m}^{3}$ laying on a network of faults compromising the exploitation of this limestone deposit. The interpretation of these data shows that this network of faults is clearly highlighted as 2D/3D structures consolidated showing a low potential water infiltration through these structures. This result is confirmed by the absence of confined and induced aquifer along all the profiles. From this finding, we concluded that the exploitation of this deposit is not conditioned by the water infiltration from the Dja River.
\end{abstract}

Keywords

Limestone Fault Network, Water Infiltration, 2D Magnetotelluric Inversion

\section{Introduction}

An area of limestone deposit of about 350 million $\cdot \mathrm{m}^{3}$ which is potentially exploitable for 30 years laying on an area of $7 \mathrm{~km}^{2}$ was highlighted in Southern Cameroon in the northern margin of the Congo craton based on the satellite data, petrographic and geochemical studies. The finalization of this project is partly conditioned by the behavior of water seepage which can be primarily operated through the fault system [1].

For this reason, 19 magnetotelluric surveys were implemented in the flooded zone of the project to highlight 
in general the shallow structures of the area and in particular to assess water infiltration potential of river Dja through this fault system [1]. After a review of geological and tectonic settings, we will present the data acquisition technology and the methodology through the Schmucker formulas [3], noise removal by the Jacknife variance [2], dimensional analysis by phase of Caldwell impedance tensor [4], and separation method of Groom and Bailey [4], 2D inversion with Occam code [5] will be made for the modeling of structures.

\section{Geologic and Tectonic Settings}

The Precambrian area in South Cameroon is made up of two geotectonic units: the Neoproterozoic mobile belt in the northern part that is represented by the Yaounde Group and the Ntem Complex in the southern part, which is the northwestern corner of the Congo craton (Figure 1). The Ntem Complex is divided into two main structural units: the Nyong Unit, to the northwest end, and the Ntem Unit, in the south-central area. These units are distinguished on the basis of different structural features [6].

The Ntem Unit is dominated by massive and banded plutonic rocks of the charnockite suite and by intrusive tonalites, trondhjemites and granodiorites. Some of these bodies were previously dated at ca. 2.9 Ga [7].

The area under study lies in the South-eastern domain of Cameroon, located in the Ntem Unit at Bi-Mintom (Figure 1). Many microfolds, fractures and mylonites are observed [8]. A recent geological investigation [9] in the northern part of Bi-Mintom has brought to evidence the outcrops of limestone, quartzite sandstone and schist of the middle Dja (Figure 2). The sedimentary basin of Mintom is an evaporitic one having a Precambrian age. This deposit of evaporites make up part of the garnetiferous-schist serie of Upper Dja, and are analogous to those put in evidence in Gabon and Congo. They are characterized by shale level, followed by marly calcareous sequences.

\section{Methodology}

\subsection{Data Acquisition}

The equipment used in this campaign is a resistivity-meter ECA 540, this resistivity-meter is composed of two identical selective measuring outlets, associated to an acquisition and calculation system that uses a micro-processor. The data sets were collected into two perpendicular directions (TE and TM).

\subsection{Method}

Data acquisition is based on the magnetotelluric method principle [10] which mainly measures the apparent resistivity of physical environments through its fundamental relationship:

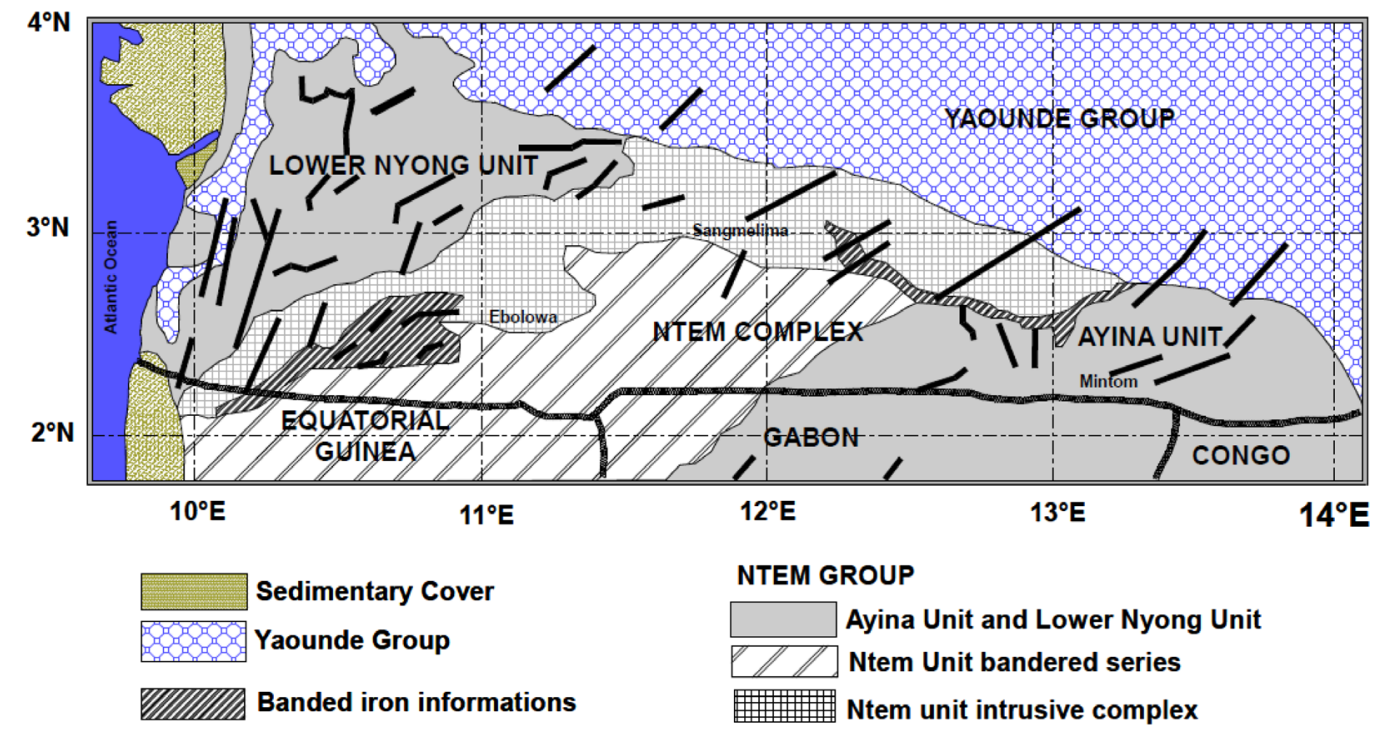

Figure 1. Simplified geological map of south Cameroon [6]. 


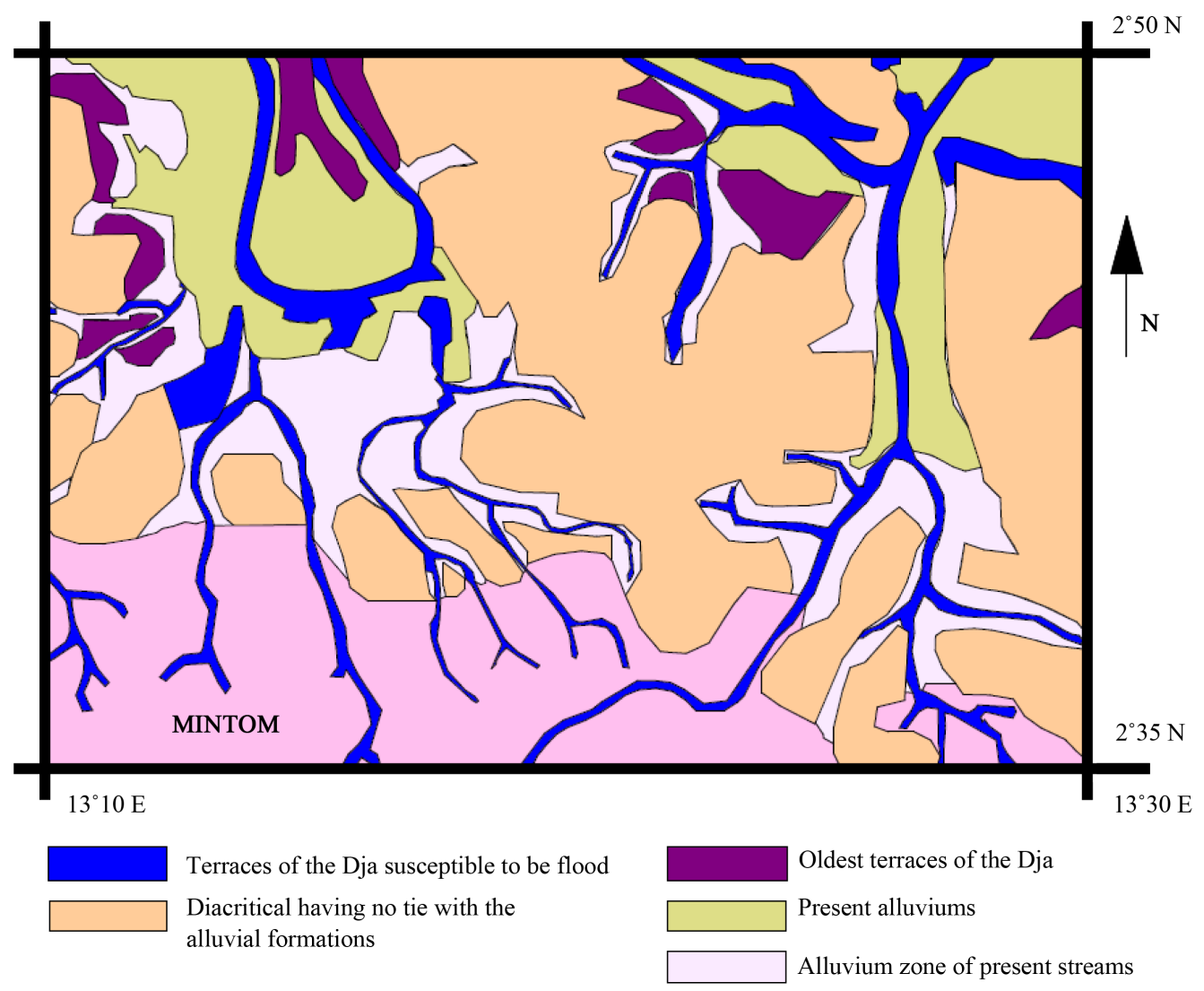

Figure 2. Local geological map simplified [16].

$$
\rho_{\|}=\frac{1}{w \mu_{o}}\left|\frac{E_{x}}{H_{y}}\right|^{2}=\frac{1}{w \mu_{o}}\left|Z_{x y}\right|^{2} ; \rho_{\perp}=\frac{1}{w \mu_{o}}\left|\frac{E_{y}}{H_{y}}\right|^{2}=\frac{1}{w \mu_{o}}\left|Z_{y x}\right|^{2} ; \mu_{o}=10^{-7} \text { henry } / \mathrm{m}
$$

In this work, measured impedance tensor will be obtained starting from Simms formula [11], SchmuckerKukes formula [12] permits to supplement the complex characterization.

$$
\varphi(w)=\frac{\pi}{4}\left(1+\frac{\mathrm{d} \log \rho_{a}(T)}{\mathrm{d} \log (T)}\right) ; 0 \leq \varphi \leq 90 \text { with } Z=|Z|(\cos \varphi+i \sin \varphi)
$$

The confidence interval of impedance tensor will be estimated in a robust way by Jackknife variance estimation [2] [13].

$$
\hat{Z}-t_{v}\left(1-\frac{\gamma}{2}\right) \widetilde{S} \leq Z \leq \hat{Z}+t_{v}\left(1-\frac{\gamma}{2}\right) \widetilde{S}
$$

The resulting impedance tensor is given by: $Z=Z_{x x_{r}}+i Z_{x x_{q}}$ and the Caldwell complex phase tensor will be express by [4] [14] [15]:

$$
\left(\begin{array}{ll}
\phi_{11} & \phi_{12} \\
\phi_{21} & \phi_{22}
\end{array}\right)=\frac{1}{\left(Z_{x x_{r}} Z_{y y_{r}}-Z_{x y_{r}} Z_{y x_{r}}\right)}\left(\begin{array}{ll}
Z_{y y_{r}} Z_{x x_{q}}-Z_{x y_{r}} Z_{y x_{q}} & Z_{y y_{r}} Z_{x y_{q}}-Z_{x y_{r}} Z_{y y_{q}} \\
Z_{x x_{r}} Z_{y x_{q}}-Z_{y x_{r}} Z_{x x_{q}} & Z_{x x_{r}} Z_{y y_{q}}-Z_{y x_{r}} Z_{x y_{q}}
\end{array}\right)
$$

Dimensional analysis parameters can be express by:

$$
\begin{aligned}
& \phi_{\min }=\left(\phi_{1}^{2}+\phi_{3}^{2}\right)^{1 / 2}-\left(\phi_{1}^{2}+\phi_{3}^{2}-\phi_{2}^{2}\right)^{1 / 2} \\
& \phi_{\max }=\left(\phi_{1}^{2}+\phi_{3}^{2}\right)^{1 / 2}+\left(\phi_{1}^{2}+\phi_{3}^{2}-\phi_{2}^{2}\right)^{1 / 2}
\end{aligned}
$$




$$
\begin{gathered}
\beta=\frac{1}{2} \arctan \left(\frac{\phi_{3}}{\phi_{1}}\right) \\
\text { where } \phi_{1}=\frac{1}{2}\left(\phi_{11}+\phi_{22}\right) ; \phi_{2}=\sqrt{\left(\phi_{11} \phi_{22}-\phi_{12}+\phi_{21}\right)} ; \phi_{3}=\frac{1}{2}\left(\phi_{12}-\phi_{21}\right)
\end{gathered}
$$

If the phase tensor is symmetric $(\beta=0)$ the principal values of the tensor are equal to its Eigen values. This situation occurs where the regional conductivity distribution is mirror symmetric, e.g. where the regional conductivity distribution is $1 \mathrm{D}$ or 2D. Where $\boldsymbol{\Phi}$ is symmetric and has equal principal values, such as is the case if the conductivity distribution is uniform or $1 \mathrm{D}$, the electric field will be linearly polarized if the magnetic field is linearly polarized. In the 2D case, the principal values will usually be distinct (i.e. $\phi_{\max }=\phi_{\min }$ ) and there will be two directions for which a linearly polarized magnetic field will give rise to a linearly polarized electric field. The 2D Impedance tensor will be derived from Groom and Bailey factorization [5].

\section{Results and Discussion}

\subsection{Dimensional Analysis}

\section{- Profile "A"}

According to this profile, values of $\beta \approx 0$ were obtained in all stations in the area (500 m before) except at the station "A2" and "A3". Low values of $\beta$ at high depth $(2.5 \mathrm{~km})$ is obtained at the stations "A4", "A5" and "A6" foreseeing the presence of superficial and deep 3D structures in these stations, and 3D superficial structure's for the rest (Figure 3) [15].

These results are in accordance with the existing geological data where a superficial limestone deposit equivalent to 3D structures has been highlighted [1].

Superficial variations (100 m) of $\left|\phi_{\max }-\phi_{\min }\right|$ were obtained on “A2”, before being zero, assuming the presence of surface 2D structures and deep 1D structures (Figure 4).

At “A3", where $\beta \neq 0$ on surface, globally, low values of $\left|\phi_{\max }-\phi_{\min }\right|$ is observed and suggest the presence of 2D structures (Figure 5).

This fault system must be included in the network of faults characteristic of Mintom area where tectonic data have detected a concentration of lineaments in the Congo Craton.

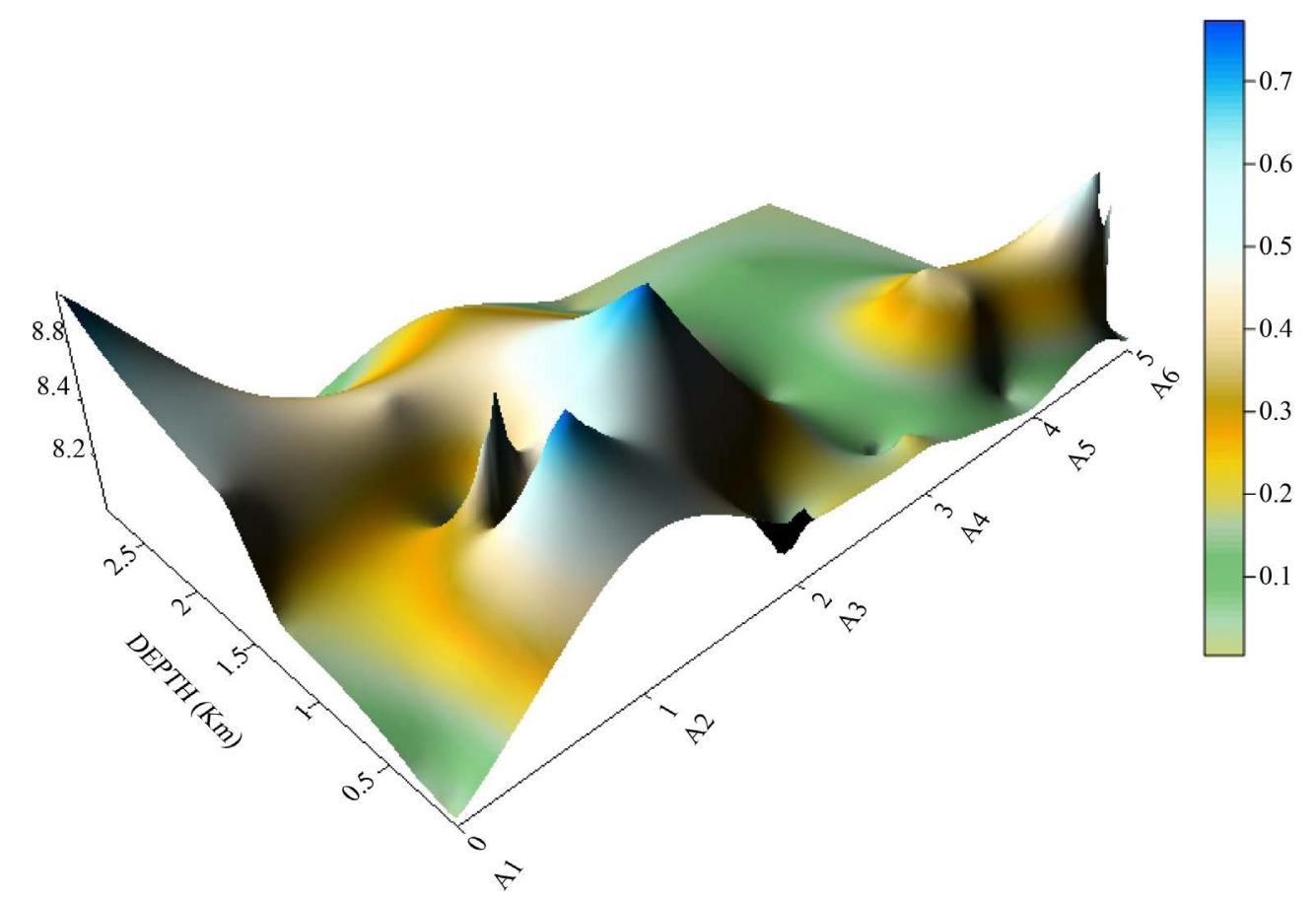

Figure 3. $\beta$ values on Profile “A”. 


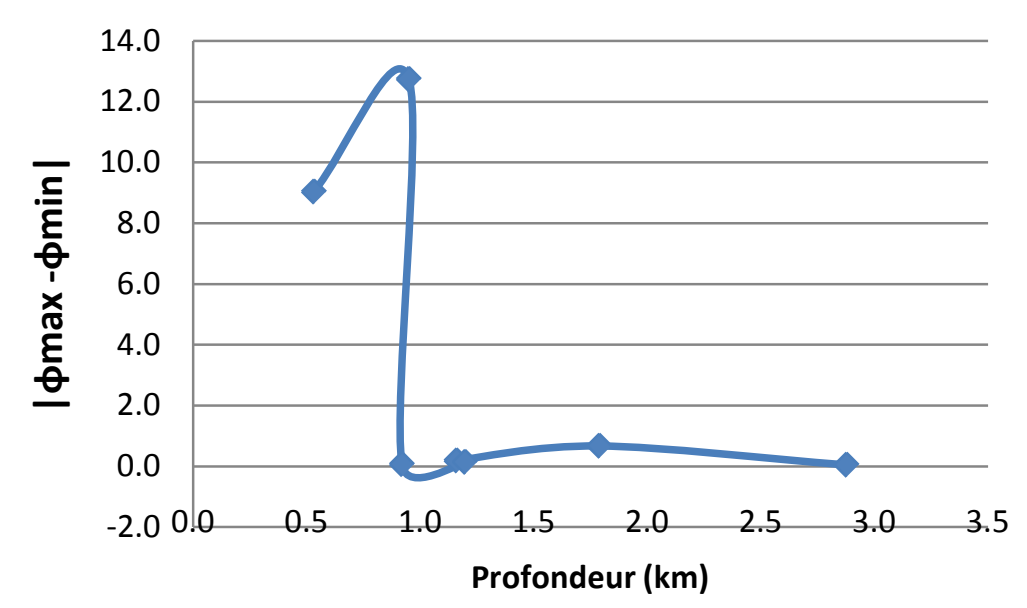

Figure 4. $\left|\phi_{\max }-\phi_{\min }\right|$ values on “A2”.

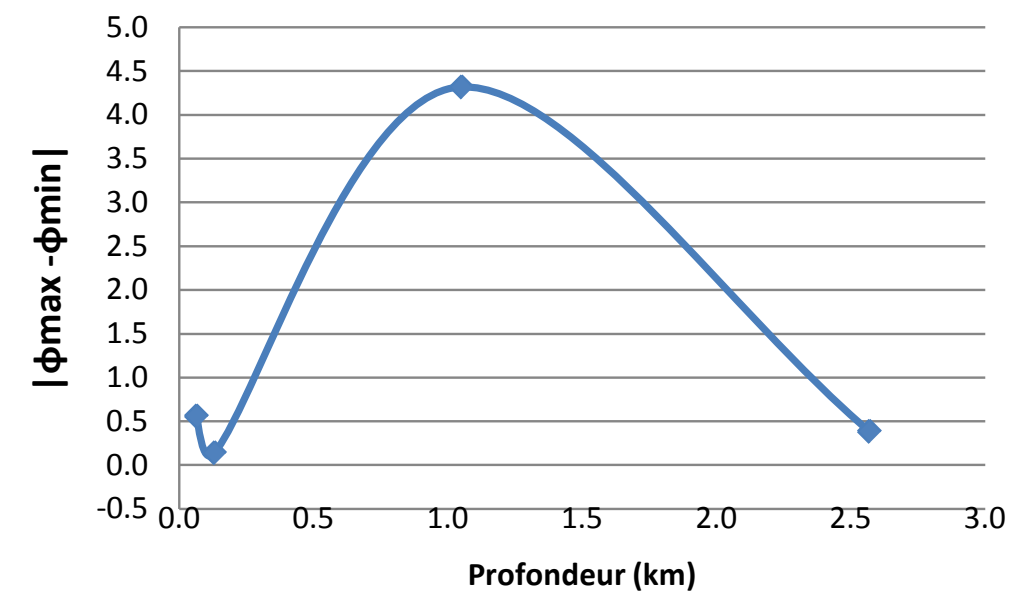

Figure 5. $\left|\phi_{\max }-\phi_{\min }\right|$ values on “A3”.

\section{- Profile "B"}

According to this profile, $\beta$ values close to zero were generally obtained at "B1", "B2", "B3", "B5" and "B6" assuming the presence of 3D structures (Figure 6).

These results also highlight the presence of 3D structures comparable to limestone deposit observed from satellite radiography and data field.

At "B4" in which non-zero values of $\beta$ were recorded, high values of $\left|\phi_{\max }-\phi_{\min }\right|$ were observed in depths, foreseeing the presence of $2 \mathrm{D}$ structures on the surface, whereas in "B7" high values of $\beta$ were correlated with high values of $\left|\phi_{\max }-\phi_{\min }\right|$ foreshadowing the presence of 2D structures (Figure 7 and Figure 8).

2D structures assimilated to faults are observed at "B4" and "B7", these are probably part of the network fault presumed lineaments.

\section{- Profile “C”}

Along this profile, $\beta$ values are generally superficially close to zero before climbing sharply from $1.5 \mathrm{~km}$, suggesting that superficial 3D structures are deposited on 1D or 2D structures (Figure 9).

The observation of these 3D structures assimilated to limestone along 8km confirms the relevance of this limestone deposit.

$\left|\phi_{\max }-\phi_{\min }\right|$ values are almost zero at "C3" and "C4" which confirm the presence of deep tabular structures overcome by 3D structures (Figure 10 and Figure 11).

Absence of 2D structures assimilated to faults shows that the network fault plans by lineaments is not locally distributed in the limestone deposit but is left in Mintom area. 


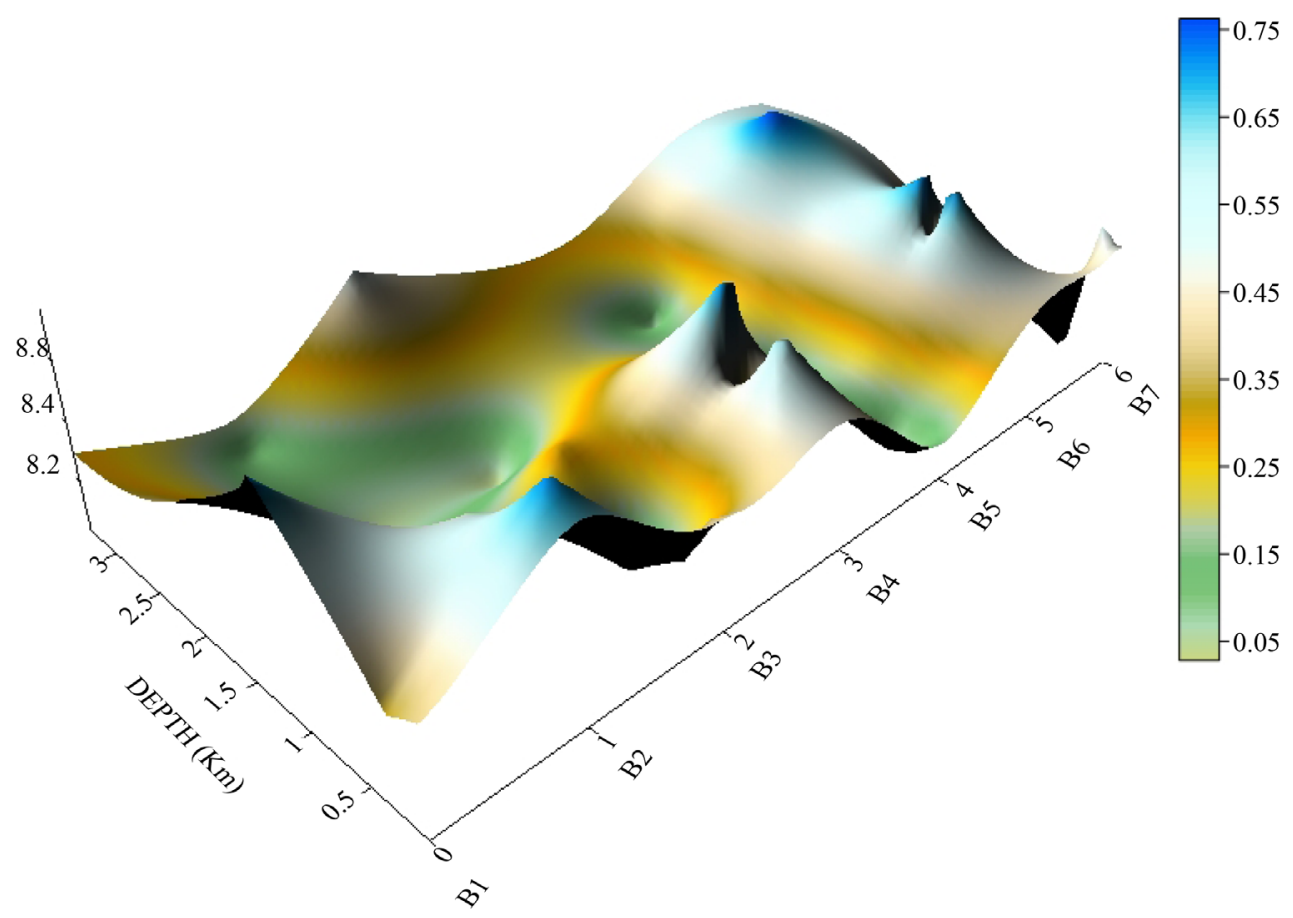

Figure 6. $\beta$ values on Profile "B".

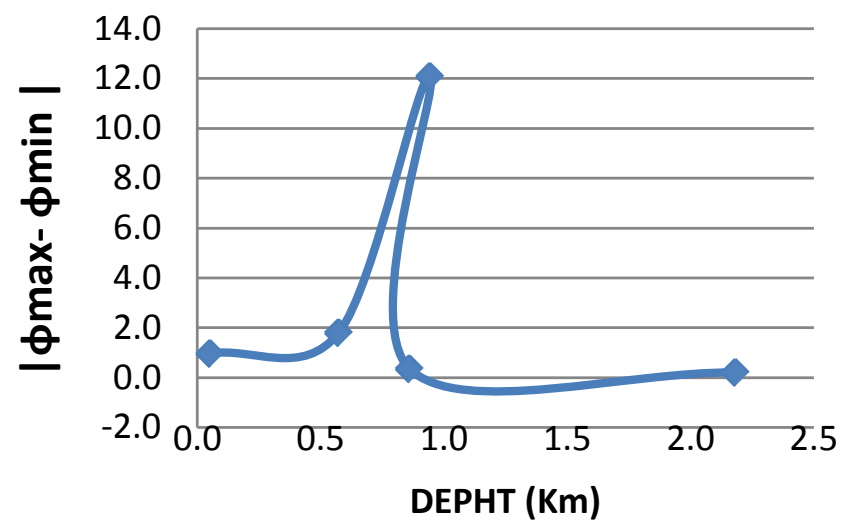

Figure 7. $\left|\phi_{\max }-\phi_{\min }\right|$ values on “B4”.

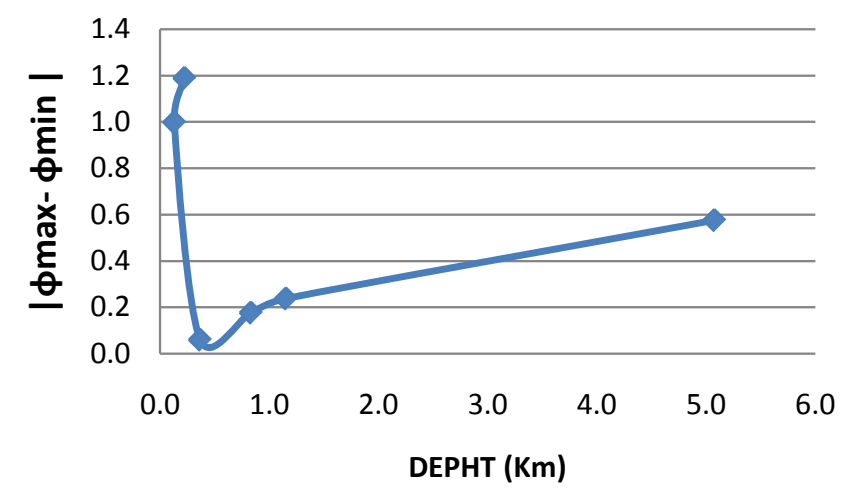

Figure 8. $\left|\phi_{\max }-\phi_{\min }\right|$ values on “B7”. 


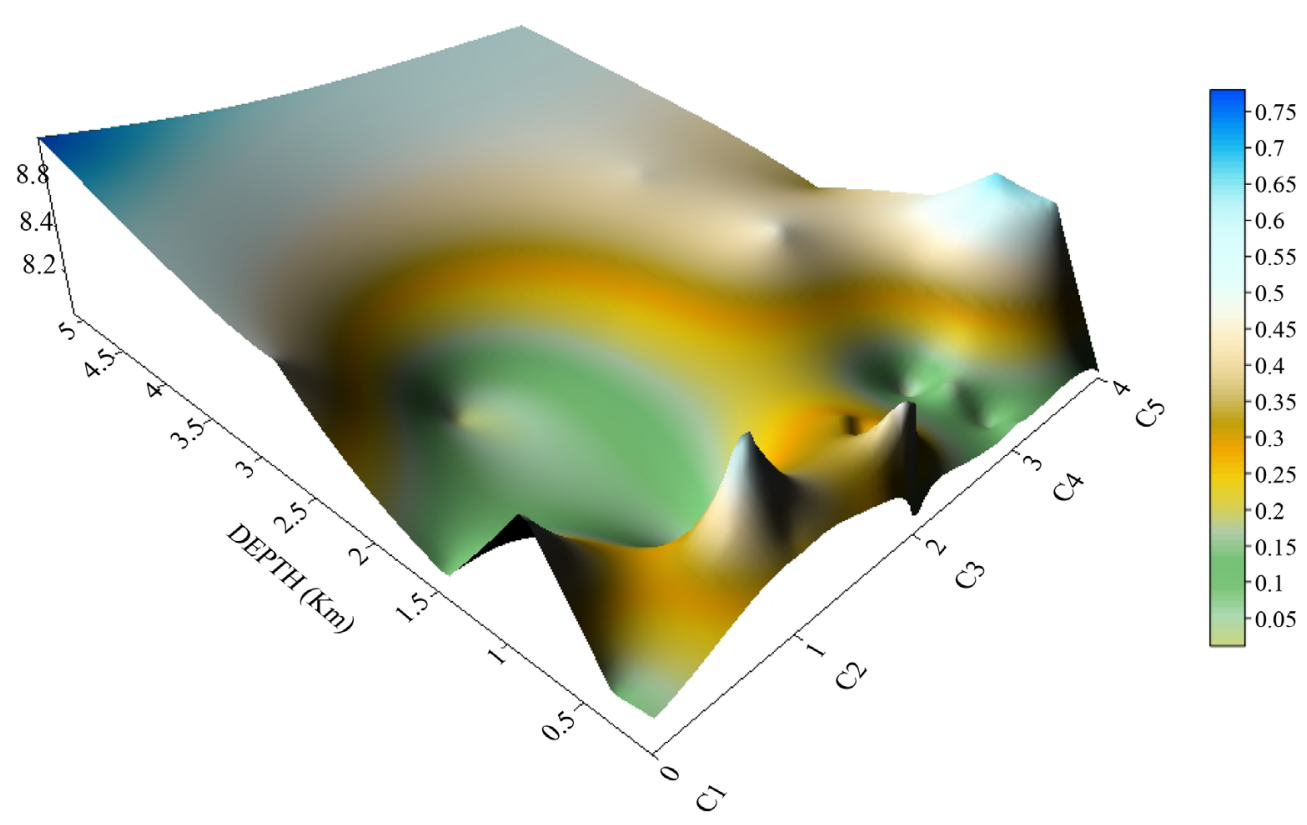

Figure 9. $\beta$ values on Profile "C".

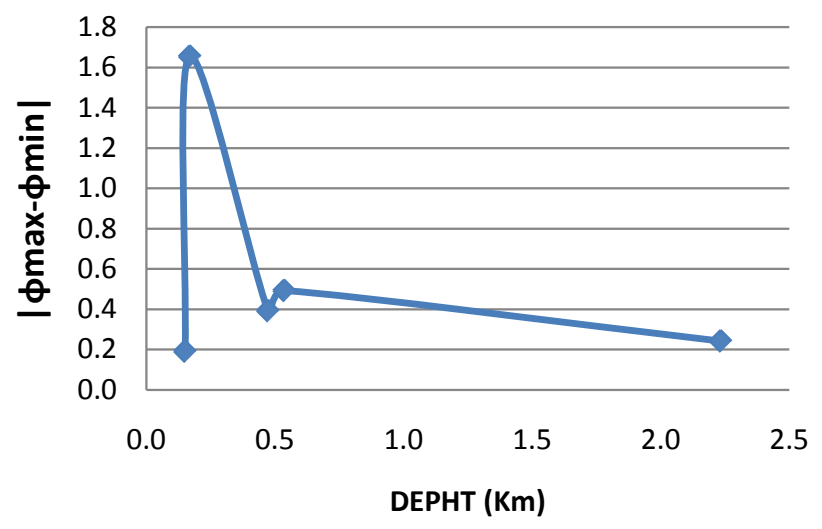

Figure 10. $\left|\phi_{\max }-\phi_{\min }\right|$ values on “C3”.

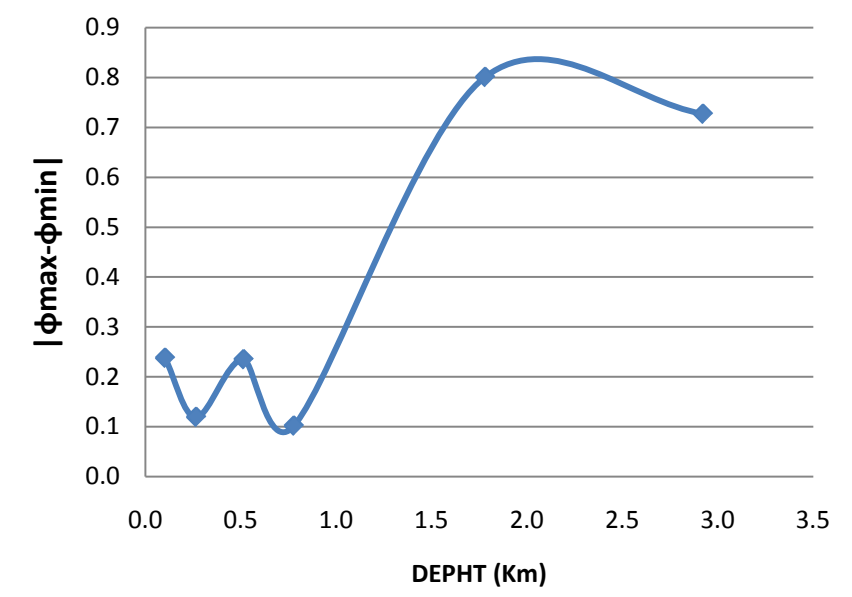

Figure 11. $\left|\phi_{\max }-\phi_{\min }\right|$ values on “C4". 


\subsection{D Inversion}

The inversion data from Occam code was made following all stations simultaneously a profile for resistivity and phase following the TM and TE modes. For this, a graphic representation of resistivity profiles based on five-color range was emerged in the interpretation of data.

\section{- Profile "A"}

A surface range (blue) of between $590-2100 \Omega \cdot \mathrm{m}$ is observable along this profile with a peak generally of around $100 \mathrm{~m}$ and picks up $150 \mathrm{~m}$ where superficial 3D structures have generally been highlighted except to “A2".

A second line (green) between 2000 and $7700 \Omega \cdot \mathrm{m}$ is observable in the first all stations with deep roots to "A3" and a surface appearance at "A2", it should be noted that 2D structures deep and superficial respectively, were highlighted in these stations (Figure 12).

The third range of resistivity (yellow) between 7700 and 28,000 $\Omega \cdot \mathrm{m}$ is as the lower roof of the second range.

The fourth range of resistivity (red color), whose values are comprised between 28,000 and 100,000 $\Omega \cdot \mathrm{m}$ shows no incrustation in the third range along the profile.

\section{- Profile "B"}

To a range between $500-2100 \Omega \cdot \mathrm{m}$ is observed along this profile along a roof of around 150 meters deep in places, 3D structures can generally been highlighted by dimensional analysis except "B7".

The second range between 2100 and $7700 \Omega \cdot \mathrm{m}$ is observable under the first except "B6" or it is surface with a deep root, deep 2D structures have been highlighted at this station (Figure 13).

The third range is between 7100 and 27,000 $\Omega \cdot \mathrm{m}$ and the fourth between 27,000 - 100,000 $\Omega \cdot \mathrm{m}$ exhibit no incrustation in the third range along the profile.

\section{- Profile "C"}

According to this profile a first range whose values vary between $470-1000 \Omega \cdot \mathrm{m}$ is observed at all stations or 3D structures were recorded.

A second range between 1000 - $2200 \Omega \cdot \mathrm{m}$ is observable without deep inlays but with near surface appearances "C2" and "C3" where 2D structures have been recorded in a few isolated depths.

The third and fourth resistivity ranges are respectively between $2200-4700 \Omega \cdot \mathrm{m}$ and between $4700-100,000$ $\Omega \cdot \mathrm{m}$ are stacked again without incrustation which bodes of the presence of 3D surface structure below which arise globally tabular structures (Figure 14).

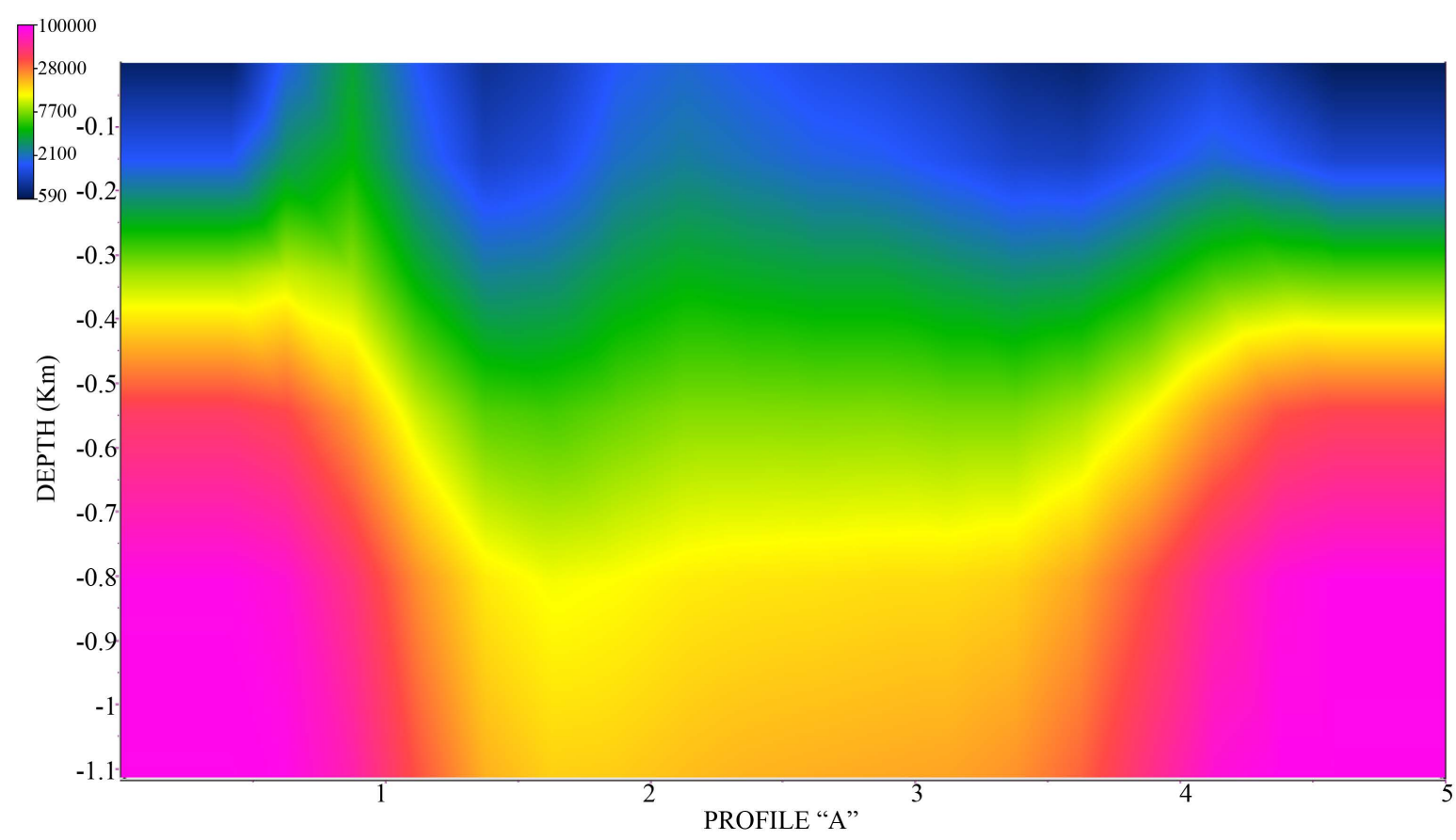

Figure 12. Calculated apparent resistivity and phase on Profile "A”. 


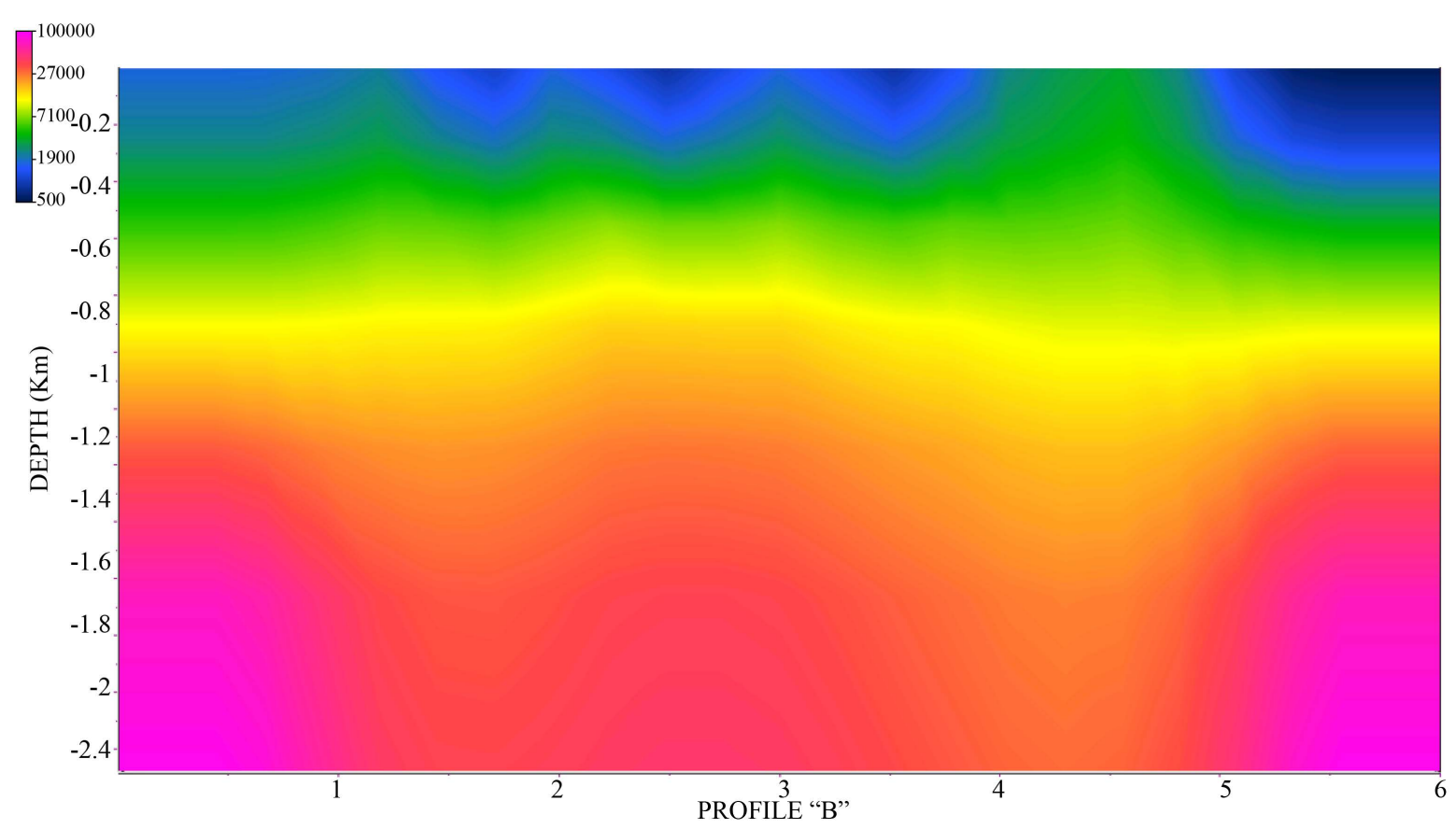

Figure 13. Calculated apparent resistivity and phase on Profile "B”.

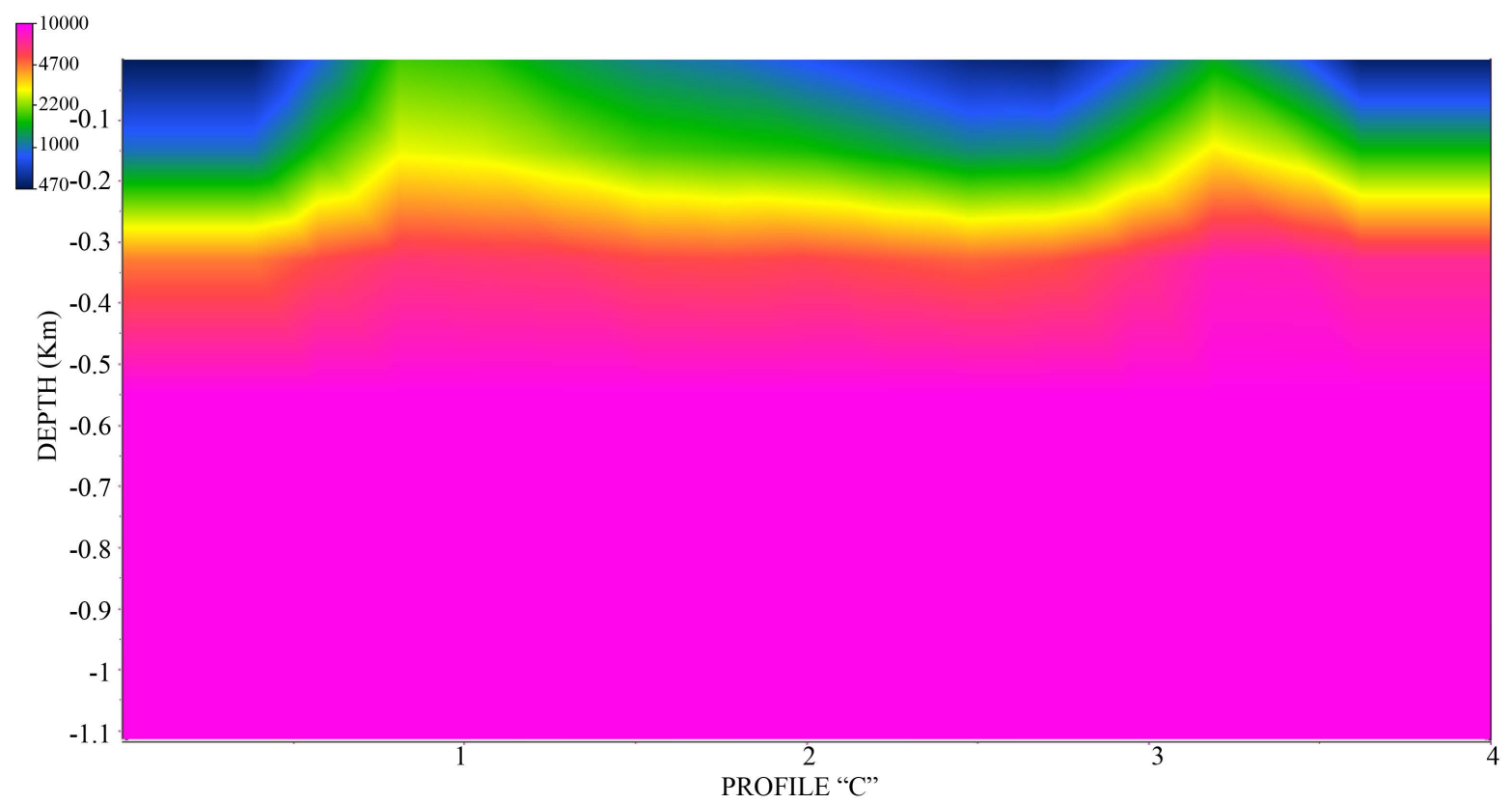

Figure 14. Calculated apparent resistivity and phase on Profile “C”.

After this plant cover the first range of resistivity ranges between 500 - $2000 \Omega \cdot \mathrm{m}$ broadly is comparable to consolidated calcareous structures as superficial 3D structures have been highlighted following all profiles. This result shows that the roof of the limestone structures varies between 100 and $150 \mathrm{~m}$, an average of 100 meters is possible which confirms the deposit to $350 \mathrm{million} \cdot \mathrm{m}^{3}$ [1].

After the foregoing operation of the resistivity curves in the three profiles and information from the exploitation of geological wells [1], it is appropriate to interpret the above structures in a pattern of five layers. The first layer being the vegetation cover following geological well having a thickness ranging from 5 to 10 meters with a resistivity generally less than $500 \Omega \cdot \mathrm{m}$. 
The second range of resistivity globally between 2000 - $7000 \Omega \cdot \mathrm{m}$ with superficial and deep appearances and varying thickness is similar to Precambrian gneiss-granite structures characteristic of this study area [7]. Presence of 2D structures to the station “A2”, “A3”, "B6”, “C2” and “C3” correlates with deep or superficial appearance of granite-gneiss these structures show the presence of many faults a control intense tectonic activity having implemented a rugged terrain [6].

The third range $7000-30,000 \Omega \cdot \mathrm{m}$ is similar to the structures of sin granites former tectonic characteristic thickness of the low area and when the granite base is represented by the fourth range between 30,000-100,000 $\Omega \cdot \mathrm{m}[6]$.

In view of the above, it appears that 2D structures comparable to the superficial and deep faults highlighted part of the network of faults developed along the Dja river with a NNW-SSE direction over $60 \mathrm{~km}$ [1].

The observation values of $\beta$ in this area reach peaks at certain depths with values generally rotating from zero to high values on the same station, it is the case according to Caldwell 2D/3D structures [4]. This suggests that the matrix of these structures is cemented thereby limiting the infiltration capacity of aquifers through this network of consolidated vulnerabilities. Similarly induced or any confined water table could be highlighted in the framework in the geoelectric models, which confirms the low capacity of water infiltrations through the limestone deposit [16] [17].

\section{Conclusions}

The interpretation of magnetotelluric data has helped to highlight the medium calcareous thicknesses consolidated to about $100 \mathrm{~m}$, this confirms a deposit estimated at about $350 \mathrm{million} \cdot \mathrm{m}^{3}$, which are overall supplanted by a network of faults developed along the Dja river and witnesses an old tectonic activity.

However dimensional analysis Caldwell has found that these flaws are size 2D/3D and 2D inversion code from OCCAM found no superficial or deep anomaly similar to an aquifer through this fault system. These results show that the fault system is consolidated and its cemented matrix limits water infiltration, moreover the network fault plans by lineaments are not locally distributed in the limestone deposit but are left in Mintom area.

\section{Acknowledgements}

The authors would like to thank the late Mr. Philippe NKOUNGOU MBA, Mr. Jeannot NOUCK, Mr. Raphael ASSAMBA and Mrs. Julienne Ngo MATIP for theirs general comments and suggestions. They also want to thank Mrs. Esther BINDANG MBOT for the financial support.

\section{References}

[1] Vanhoutte, M. and Salley, P. (1986) Reconnaissance des calcaires de Mintom: Projet de recherches minières, sud-est Cameroun. United Nations Development Program, Unpublished Report 1046 91, 59.

[2] Jone, A.G., Chave, A.D., Egbert, G.D., Auld, D. and Bahr, K. (1989) A Comparison of Techniques for Magnetotelluric Response Function Estimation. Journal of Geophysical Research, 94, 14201-14213.

[3] de Groot-Hedlin, C. and Constable, S. (1990) Occams’ Inversion to Generate Smooth Two-Dimensional Models from Magnetotelluric Data. Geophysics, 55, 1613-1624. http://dx.doi.org/10.1190/1.1442813

[4] Caldwell, T.G., Bibby, H.M. and Brown, C. (2004) The Magnetotelluric Phase Tensor. Geophysics Journal International, 158, 457-469. http://dx.doi.org/10.1111/j.1365-246X.2004.02281.x

[5] Groom, R. and Bailey, R.C. (1989) Decomposition of the Magneto Telluric Impedance Tensor in the Presence of Local Three-Dimensional Galvanic Distortion. Journal of Geophysical Research, 94, 1913-1925.

[6] Maurizot, P., Abessolo, A., Feybesse, J.L., Johan, V. and Lecomte, P. (1985) Etude et prospection minière du SudOuest Cameroun, Synthèse des travaux de 1978 à 1985, Rapp. BRGM, Orléans, 85, CMR 066, 274 p.

[7] Toteu, S., Fouateu, R., Penaye, J., Tchakounte, J., Mouangue, A., Van Schmuss, W., Deloule, E. and Stendal, H. (2006) U-Pb Dating of Plutonic Rocks Involved in the Nappe Tectonics in Southern Cameroon: Consequence for the PanAfrican Orogenic Evolution of the Central African Fold Belt. Journal of African Earth Sciences, 44, 479-493. http://dx.doi.org/10.1016/j.jafrearsci.2005.11.015

[8] Regnoult, J.M. (1986) Synthèse géologique du Cameroun, Ministère Mines et Energie. D.M.G. Yaoundé, Cameroun .P. 61-80.

[9] Caron, V., Ekomane, E., Mahieux, G., Moussango, P. and Ndjeng, E. (2010) The Mintom Formation (New): Sedimentology and Geochemistry of a Neoproterozoic, Paralic Succession in South-East Cameroon. Journal of African Earth 
Sciences, 57, 367-385. http://dx.doi.org/10.1016/j.jafrearsci.2009.11.006

[10] Cagniard, L. (1953) Basic Theory of the Magneto Telluric Method of Geophysical Prospecting. Geophysics, 18, 605635.

[11] Sims, W.E., Bostick, F. and Smith, W. (1971) The Estimation of Magnetotelluric Impedance Tensor Elements from Measured Data. Geophysics, 36, 938-942. http://dx.doi.org/10.1190/1.1440225

[12] Weidelt, P. (1972) The Inverse Problem of Geomagnetic Induction. Journal of Geophysics, 38, 257-289.

[13] Lilley, F. (1998) Magnetotelluric Tensor Decomposition: Part II, Examples of a Basic Procedure. Geophysics, 63, 1898-1907. http://dx.doi.org/10.1190/1.1444482

[14] Vozzof, K. (1972) The Magnetotelluric Method in the Exploration of Sedimentary Basins. Geophysics, 37, 98-114.

[15] Nkoungou, E., Nouck, N. and Manguelle, D. (2014) Electromagnetic Impedance and Phase Studies in Seismic Precambrian Area. European Journal of Scientific Research, 122, 443-445.

[16] Nkoungou, H.L.E., Nouck, P.N., Bisso, D., Assembe, S. and Dicoum, E.M. (2012) Geophysical Contribution for the Determination of Aquifer Properties in Memve Ele, South Cameroon. Journal of Water Resource and Protection, 4, 885-890. http://dx.doi.org/10.4236/jwarp.2012.410104

[17] Meli’i, J., Njandjock Nouck, P., Mbanga, A. and Manguelle-Dicoum, E. (2012) Spatial Analyses of Magnetotelluric Data in the Northern Part of Congo Craton in South Cameroon Region. Journal of Emerging Trends in Engineering and Applied, 3, 631-635. 